\title{
Evaluation of Economic Efficiency of using Resource Saving Technologies (Conservation Agriculture) in Irrigated Lands
}

\section{Rustamova IB ${ }^{1 *}$}

${ }^{1}$ Department of Agricultural Economics, Agrarian University, Tashkent State, Uzbekistan

\begin{abstract}
Global climate change, reduction in planting areas, land degradation, limited water resources, and ecologic problems influence food security directly. The role and importance of resource saving technologies (conservation agriculture) is increasing considerably high in intensive development of agriculture of Uzbekistan.

The objective of the research is economic evaluation of wheat production under conservation agriculture practices in irrigated lands. Economic indicators show that winter wheat production under conservation agriculture is more efficient than under conventional agriculture practices.

For the purpose of economic evaluation of conservation and conventional agriculture practices, full costs and profit are taken for winter wheat production.

Under resource saving technologies (conservation agriculture) in 1 ha, fossil fuels are saved by $53 \%$, and economic efficiency is 1141825.8 (\$ 456) sums.
\end{abstract}

Keywords: Resource saving technologies (conservation agriculture); Minimum and zero tillage, Economic evaluation; Efficiency; Costs; Timing of cost recovery; Productivity

\section{Introduction}

Taking measures in order to increase economic efficiency of agricultural production is crucial due to at least two actual issues that demand for food is increasing all over the world and energy resources are decreasing. In these measures, not only quantity criteria in agricultural production should be given priority but also usefulness, sustainability, and ecologic qualities in agricultural production should be taken into account. Around 700 million ha are used for cereal production all over the world and resource saving technologies (conservation agriculture) is being employed in 400 million ha out of that [1].

Global climate change, reduction in plant areas, land degradation, limited water resources, and ecologic problems influence food security directly. The role and importance of resource saving technologies (conservation agriculture) is increasing considerably high in intensive development of agriculture of Uzbekistan.

Conservation agriculture (CA) technologies are one of the perspective and sustainable ways in the usage of agricultural lands. It is better to call conservation agriculture practices instead technologies. Because, this practice encompasses a variety of ways to support to keep soil humidity and to increase organic matters in the soils. For example, in CA, the decomposition process of surface crop residue takes less time, soil quality increases due to that: flora and fauna of soil keep organic matters longer time, rain water infiltration to the soil increases permanent vertical macro-ways in soils, water evaporation from the soil decreases due to undisturbed soil, water productivity increase due to less watering and decrease in the soil erosion, and organic matters in the soil keeps water for the plant ( $1 \%$ organic matter $\left.=150 \mathrm{~m}^{3} / \mathrm{ha}\right)$. As a result of this, demand of plants for water reduces by $30 \%$ no matter of how watering conditions or precipitation are [1].

Additionally, in scientific articles conservation agriculture (CA) is characterized by three criteria: minimal soil disturbance, crop rotation, and surface crop residue retention [2]. CA includes many changes in land use and water use in contrast with conventional agriculture.
Moreover, there is a requirement for not only technical changes but also attitude of farmers or users to implement CA. Water conservation through CA (except water conservation, there are many benefits of $\mathrm{CA})$ is essential to prevent salinity and land degradation in Central Asia [3]. According to Ken EG [4], CA is one of the options to combat environmental issues such as land degradations and water scarcity.

At the present time, many farmers are not using widely conservation agriculture (CA) technic in their agricultural practices in Uzbekistan. There are some factors that influence the implementations of CA, but one of the main reasons is considered as a lack of jointly collaborative work between actors [5].

The implementations of CA in the parts of Uzbekistan where water scarcity and land degradation exist are crucial that gives a chance to mitigate and adapt to those problems.

Considers that conventional ways of tillage activities consist of some technics such as [6]:

- Clearing the land from residues after harvest

- Plough (turns over the soil completely)

- Chisel (breaks and mixes the soil)

- Disc (inverts the soil)

- Cultivation (mixes the soil)

- Sowing

*Corresponding author: Rustamova IB, Department of Agricultural Economics, Agrarian University, Tashkent State, Uzbekistan, Tel: +31317480100; E-mail: irodarustamova@mail.ru

Received May 17, 2016; Accepted June 23, 2016; Published June 27, 2016

Citation: Rustamova IB (2016) Evaluation of Economic Efficiency of using Resource Saving Technologies (Conservation Agriculture) in Irrigated Lands. J Glob Econ 4: 197. doi:10.4172/2375-4389.1000197

Copyright: $\odot 2016$ Rustamova IB. This is an open-access article distributed under the terms of the Creative Commons Attribution License, which permits unrestricted use, distribution, and reproduction in any medium, provided the original author and source are credited. 
Mention that there are negative sides of conventional agriculture on different points such as [7]:

- Soil moisture loss

- Risk of erosion

- Destruction of the soil structure

- High operational costs

- Dependence on time, power and equipment

Also, disturbing soil in terms of agricultural cultivation damages soil quality, particularly, humus patterns. It has severe effects on microorganism, microbiology, soil structure, nutrients and others in soil [8]. Furthermore, [9] concludes following points based on her research:

- CA is less costly and users of CA can save $45 \%$ of fuel and $20 \%$ of labour costs compare to conventional technology

- Compared to conventional, CA demands additional cost for herbicide usage to different weeds

- Implementation of CA technology is not limited from policy regulations but it is required to more support and promote from government to widely usage of it

Conservation agriculture can give a possibility to use land resources sustainably, to prevent soil erosion (land degradation as well), to improve land management practices and solve several issues in agricultural production in terms of fossil fuels usage.

In Uzbekistan, the output of cereals, vegetables, potatoes, fruits is increasing and the amount of cotton production in the areas is decreasing simultaneously. This is very important to avoid the lack of food and high prices for them. As a consequence of increase in harvesting of agriculture production and a decrease in the amount of cotton area, in 1991 cotton production was 4646 thousand tons, and in 2015 it was 3497.2 thousand tons (decrease $24.8 \%$ relative to 1991 ). Cereal production increased from 1908.2 to 7500 thousand tons, in 1991 and 2015 respectively (increase $25.4 \%$ relative 1991). These indicators of agricultural products provide to cover all demand of Uzbekistan and give a chance to export these products sustainably $[10,11]$.

Due to implementation of conservation agriculture and other agro innovation measures, the harvesting of agricultural products increased and this indicator (one of the others) shows economic efficiency in agricultural production $[10,11]$.

\section{Materials and Methods}

In the framework of the project "Knowledge Management" initiated by Central Asian Countries Initiative for Land Management of International Center for Agricultural Research in the Dry Area (ICARDA), an agronomist A. Nurbekov did experiment on conservation agriculture practices in 600 ha of rain fed lands and in 100 ha of irrigated lands [1].

We evaluated economic indicators for winter wheat production in irrigated lands (100 ha) and in rain fed lands (600 ha) based on the experiment. As a result of the implementations of the CA, it is also expected that a decrease in expenses of agricultural production (material costs, labour costs and etc.), improvement in working conditions, modernization of the technologies used for agriculture.

Economic evaluation of resource saving technologies and conventional agriculture are carried out based on the following sequences.

- economic evaluation indicators for both practices are identified;

- the purpose and task of the calculations are pointed;

- case study (as an example private farming) is selected;

- economic indicators of the private farming are identified;

- statistic data about agricultural lands, irrigated or rain fed lands, yields, costs (tangible), and prices for selling and buying are identified;

- technic- economic indicators for resource saving technologies (conservation agriculture) and conventional agriculture are calculated and compared;

- technologic calculation maps are provided for agricultural production;

- net costs of agricultural products are calculated;

- main and additional economic indicators are given based on basis and new versions and alternative versions are identified [12].

\section{Results}

Economic evaluation was done after implementation of the minimal and zero tillage practices for winter wheat production. The author gave these results from the case of private farming "Anvar Jabborov" in Kashkadarya Province [13].

To calculate economic efficiency, preliminary and normative technologic map data are used.

Expenses in conventional agriculture of wheat production were compared with conservation agriculture and this means that conventional agriculture indicators were employed as a basis for the calculation.

Minimal and zero tillage technologies mutually were compared. In minimal practices, small surface cultivation is done instead of plowing or chiselling deeply. This provides a reduction in technologic operations, less soil disturbance, an increase in humus in the soil content, a decrease in soil erosion.

Zero tillage practices do not disturb the soil and this leads to improve humus condition of the soil. For zero tillage, special aggregates are employed to sow and cultivate wheat plants.

The combination of using minimal and zero tillage practices reduces mechanic influences to the soil and its dense. In this case, in wheat production, material and labour costs are economized. Minimal and zero tillage practices are implemented to the agricultural plants (different types of plants) that are sowed before autumn wheat production. In wheat production, cultivating the soil before sowing, and different methods of sowing are taken into account. Cultivating plants, giving organic minerals are the same.

Minimal and zero tillage practices (CA practices) demand special machines and its instruments to use that take into account soil, climate conditions.

In this research, mechanization services are considered to be provided by machine tractors parks in the regions.

For this purpose, ARION-630C, TTZ LS 100 HC, TTZ LS PLUS 100 
tractors, Class Dominator 130 wheat combine harvester are used. They will provide mechanization services on time with high quality [14].

Technologic operations of winter wheat production in farming are based on regional conditions for aggregates, methods of wheat planting and harvesting, unification on the same works, increasing the yield, decrease negative effects of the machines on the soils, and programme for 2011-2016 on complex mechanization of the agricultural production and improve the condition of provision with technics [14].

Costs were calculated under assumption of that technologic processes (works) were done by main machines. The list of the work needed to be done, aggregates, costs are given in Table 1 . The normativetechnologic map was formulated which shows technologic operations of wheat production, material and labour costs. Based on this map, costs were calculated for wheat production technologies.

These expenses were the part of net cost of wheat production and made up $30-40 \%$ of costs.

The least expenses were observed under zero tillage technology and this demanded to use special technics for operations (sowing, harvesting etc.). However, minimal technology used local technics and instruments for the wheat production. In this case, the soil was not ploughed. Although, this technology spent less expense, its costs were higher than zero tillage.

According to Table 1 the expenses in conventional agriculture which uses all traditional methods of sowing, several times cultivating, harvesting and etc. were the highest among others and it made up 423635.5 thousand sums per ha.

In minimal technology, expenses were less due to fewer operations in terms of cultivating and watering and its costs were 297712. The zero tillage practices are best suitable in terms of economic indicators which spent 219703 thousand sum per ha. This was achieved by decreasing the number of operation in wheat production. The costs were calculated based on indicators of the farming activity.

Table 2 provides outcomes of using conservation agriculture practices in rain fed lands in winter wheat production.

From that, it can be seen that total costs of conventional agriculture are higher than conservation agriculture. Here, it is only from economic point of view. The advantages of conservation agriculture from ecologic perspective are much higher compared to conventional practices as well.

Table 3 provides data about the costs of seeds, minerals, pesticides for wheat production under technologies researched in irrigated land.

For 50-60 centner wheat production, $180-220 \mathrm{~kg}$ nitrogen, $110-110$ $\mathrm{kg}$ phosphorous, and 60-70 $\mathrm{kg}$ potassium fertilizers are used.
"Granstar" with 75\% is one of the herbicides to protect from weeds in irrigated and non-irrigated lands. For 1 ha, 10-20 gr of "Granstar" is needed. To protect wheat from diseases, 0.4-0.6 litter "Reks Duo" fungicide and for pest protection 0.45-0.5 litter "Dalate" insecticide are employed [15].

Other costs include sub materials: small inventors, containers, packing materials, land tax, credit payments, and others. These costs should make up to $5 \%$ of direct costs. In our calculations, up to $2 \%$ of the directs costs for the other costs were taken.

Below Table 4 shows evaluation indicators of economic efficiency by the technologies.

According to the economic indicators, it can be seen that resource saving technologies (minimal and zero tillage) are more efficient than conventional practices of wheat production.

In order to do economic evaluation of the technologies, full net costs and profit were calculated for wheat production [16-18].

The difference in net costs is based on the conditions of only expenses in soil cultivation. Other costs (for seeds, fertilizers, plant protection) were considered as same for all technologies.

The following economic indicators of profit increase for minimal and zero tillage technology.

$\operatorname{lC}_{\mathrm{M}}=\Phi_{\mathrm{M}}-\Phi_{\mathrm{T}}=1501771,7-566102,9=935668,8$ сўM

For zero tillage technology:

$\mathrm{UC}_{\mathrm{H}}=\Phi_{\mathrm{H}}-\Phi_{\mathrm{T}}=1707928,7-566102,9=1141825,8$ сўM

Here: $И_{\mathrm{M}}$ and $И_{\mathrm{H}}$ - economic efficiency under minimal and zero tillage practices respectively, in sums;

$\Phi_{\mathrm{T}}, \Phi_{\mathrm{M}}, \Phi_{\mathrm{H}}$ are profits under conventional, minimal, and zero tillage respectively, in sums.

From these above mentioned indicators, it can be stated that minimal and zero tillage is economically efficient in farming activity. The yields of wheat production were higher to 18.1 and 16.4 centner under minimal and zero tillage technologies and net costs were fewer to 139003 and 114097 sums respectively relative to conventional technology of wheat production.

Expenses in minimal and zero tillage practices were less than conventional with $26.7 \%$ and $10.5 \%$ respectively.

Evaluations including additional indicators showed that labour and fossil fuels costs were less under minimal and zero tillage practices compared with conventional technology.

Labour costs for 1 ha were 1.04 person/ha and 0.98 person/ha in

\begin{tabular}{|c|c|c|c|c|c|c|c|}
\hline \multirow{3}{*}{ No. } & \multirow{3}{*}{ Activity } & \multicolumn{6}{|c|}{ Technologies } \\
\hline & & \multicolumn{2}{|c|}{ Conventional } & \multicolumn{2}{|c|}{ Minimal } & \multicolumn{2}{|c|}{ Zero tillage } \\
\hline & & Sum & $\%$ & Sum & $\%$ & Sum & $\%$ \\
\hline 1 & Cultivating the soil & 161868,0 & 38,2 & 35948,0 & 12,1 & - & - \\
\hline 2 & $\begin{array}{c}\text { Operations before sowing and } \\
\text { sowing }\end{array}$ & 30679 & 7,2 & 30679 & 10,3 & 30679 & 14,0 \\
\hline 3 & Growing plants & 72278,3 & 17,1 & 72278,3 & 24,3 & 30217 & 13,8 \\
\hline \multirow[t]{2}{*}{4} & Yielding activity & 158807,27 & 37,5 & 158807,27 & 53,3 & 158807,2 & 72,3 \\
\hline & Total costs & 423632,5 & 100 & 297712,5 & 100 & 219703,5 & 100 \\
\hline \multirow[t]{2}{*}{5} & Fossil fuels & 265406,4 & & 191682,4 & & 141128,8 & \\
\hline & Total exploitation costs & 689038,9 & & 489394,9 & & 360832,3 & \\
\hline
\end{tabular}

Table 1: Costs of wheat production in an irrigated land (for 1 ha). 
Citation: Rustamova IB (2016) Evaluation of Economic Efficiency of using Resource Saving Technologies (Conservation Agriculture) in Irrigated Lands. J Glob Econ 4: 197. doi:10.4172/2375-4389.1000197

Page 4 of 5

\begin{tabular}{|c|c|c|c|c|c|}
\hline \multirow{2}{*}{ No. } & \multirow{2}{*}{ Activity } & \multicolumn{2}{|c|}{ Conventional } & \multicolumn{2}{|c|}{ Zero tillage } \\
\hline & & Sum & $\%$ & Sum & $\%$ \\
\hline 1 & Cultivating the soil & 80000 & 36,4 & - & - \\
\hline 2 & Operations before sowing and sowing & 30000 & 13,6 & 30000 & 24 \\
\hline 3 & Growing plants & 30000 & 13,6 & 15000 & 12 \\
\hline \multirow[t]{2}{*}{4} & Yielding activity & 80000 & 36,4 & 80000 & 64 \\
\hline & Total costs & 220000 & 100 & 125000 & 100 \\
\hline \multirow[t]{2}{*}{5} & Fossil fuels & 177190,4 & & 77978,9 & \\
\hline & Total exploitation costs & 397190,4 & & 202978,9 & \\
\hline
\end{tabular}

Table 2: Costs of wheat production in rain fed land (for 1 ha).

\begin{tabular}{|c|c|c|c|c|c|c|c|c|}
\hline \multirow[t]{2}{*}{ No. } & \multirow[t]{2}{*}{ Material Resources } & \multicolumn{3}{|c|}{ Resources by technologies } & \multirow[t]{2}{*}{ Unit } & \multicolumn{3}{|c|}{ Costs by technologies } \\
\hline & & conventional & Minimal & zero & & conventional & minimal & zero \\
\hline \multicolumn{9}{|c|}{ Seeds } \\
\hline 1. & Seeds, kg & 225 & 225 & 225 & 1101,1 & 247747 & 247747 & 247747 \\
\hline \multicolumn{9}{|c|}{ Fertilizers } \\
\hline 1. & Nitrogen (physical weight, kg) & 180 & 180 & 180 & 1599,9 & 287982 & 287982 & 287982 \\
\hline 2. & Phosphorus (physical weight, kg) & 100 & 100 & 100 & 2299,9 & 229990 & 229990 & 229990 \\
\hline 3. & Potassium (physical weight, kg) & 60 & 60 & 60 & 1400 & 84000 & 84000 & 84000 \\
\hline & Total & & & & & 601972 & 601972 & 601972 \\
\hline \multicolumn{9}{|c|}{ Plant protection } \\
\hline \multicolumn{9}{|c|}{ Weed protection } \\
\hline & Herbicide & 0,022 & 0,022 & 0,022 & 420000 & 9240 & 9240 & 9240 \\
\hline \multicolumn{9}{|c|}{ Disease protection } \\
\hline & Fungicide & 0,5 & 0,5 & 0,5 & 105000 & 52500 & 52500 & 52500 \\
\hline \multicolumn{9}{|c|}{ Pest protection } \\
\hline & Insecticide & 0,5 & 0,5 & 0,5 & 33000 & 16500 & 16500 & 16500 \\
\hline & Total & & & & & 78240 & 78240 & 78240 \\
\hline
\end{tabular}

Table 3: Costs of seeds, minerals, pesticides for wheat production in 1 ha (of irrigated land).

\begin{tabular}{|c|c|c|c|c|c|}
\hline & \multirow{2}{*}{ Indicators } & \multirow{2}{*}{ Unit } & \multicolumn{3}{|c|}{ Technologies } \\
\hline & & & Conventional & Minimal & Zero tillage \\
\hline 1 & Wheat yields & c/ha & 49,0 & 65,4 & 67,1 \\
\hline 2 & Output & $\mathrm{T}$ & 4,9 & 6,5 & 6,7 \\
\hline \multicolumn{6}{|c|}{ Production costs } \\
\hline 3 & Seed & sums & 247747,5 & 247747,5 & 247747,5 \\
\hline 4 & Fertilizers & Sums & 601972,0 & 601972,0 & 601972,0 \\
\hline 5 & Plant protections & Sums & 78240,0 & 78240,0 & 78240,0 \\
\hline 6 & Exploitation costs & Sums & 423632,5 & 297712,5 & 219703,5 \\
\hline 7 & Fossil fuels & Sums & 265406,4 & 191682,4 & 141128,8 \\
\hline 8 & Other costs & Sums & 8472,7 & 5954,3 & 4394,1 \\
\hline 9 & Total costs & Sums & 1625471,1 & 1423308,7 & 1293185,9 \\
\hline 10 & Net cost of products & Sums & 331728,8 & 217631,3 & 192725,2 \\
\hline 11 & Realization price & Sums & 447260,0 & 447260,0 & 447260,0 \\
\hline 12 & Product value & Sums & 2191574,0 & 2925080,4 & 3001114,6 \\
\hline 13 & Profit & Sums & 566102,9 & 1501771,7 & 1707928,7 \\
\hline 14 & efficiency & Sums & & 935668,8 & 1141825,8 \\
\hline 15 & Profitability & $\%$ & 34,8 & 105,5 & 132,1 \\
\hline \multicolumn{6}{|c|}{ Extra indicators } \\
\hline \multirow[t]{2}{*}{16} & Labour costs for 1 ha & person/hour-ha & 1,07 & 1,04 & 0,98 \\
\hline & & Sums & 17815 & 17197 & 16243 \\
\hline 17 & Labour costs for 1 centner & person/hour & 0,021 & 0,015 & 0,014 \\
\hline 18 & Labour productivity & sums/ person/hour & 123 & 170 & 184 \\
\hline 19 & Labour capacity & sums/ person/hour & 0,22 & 0,16 & 0,15 \\
\hline 20 & Fossil fuels & I/ha & 126,0 & 91,0 & 67,0 \\
\hline 21 & Recovery time & Year & & & 3,6 \\
\hline
\end{tabular}

Table 4: Indicators of economic evaluation for 1 ha of wheat production by technologies. 
Citation: Rustamova IB (2016) Evaluation of Economic Efficiency of using Resource Saving Technologies (Conservation Agriculture) in Irrigated Lands. J Glob Econ 4: 197. doi:10.4172/2375-4389.1000197

Page 5 of 5

\begin{tabular}{|c|c|c|c|c|c|c|}
\hline \multirow{2}{*}{ No. } & \multirow{2}{*}{ Material Resources } & \multicolumn{2}{|c|}{ Resources by technologies } & \multirow[t]{2}{*}{ Price per unit } & \multicolumn{2}{|c|}{ Costs by technologies } \\
\hline & & conventional & Zero & & conventional & zero \\
\hline \multicolumn{7}{|c|}{ Seeds } \\
\hline 1 & Seeds, kg & 100 & 100 & 1101,1 & 110110 & 110110 \\
\hline \multicolumn{7}{|c|}{ Fertilizers } \\
\hline \multirow[t]{2}{*}{1} & Nitrogen (physical weight, kg) & 60 & 60 & 1599,9 & 95994 & 95994 \\
\hline & Total & & & & 95994 & 95994 \\
\hline \multicolumn{7}{|c|}{ Plant protection } \\
\hline & Herbicide kg/ha & 0,01 & 0,02 & 81536 & 8153 & 16307 \\
\hline
\end{tabular}

Table 5: Costs of seeds, minerals, pesticides for wheat production in 1 ha (of rain fed land).

minimal and zero tillage practices respectively. This was 1.07 person/ha in conventional technology.

Labour costs for 1 tons were 0.15 person/ha and 0.14 person/ha in minimal and zero tillage practices respectively. This was 0.21 person/ha in conventional technology.

Fossil fuels costs were less as well in resource saving technologies. In terms of figures, it was $91 \mathrm{l} / \mathrm{ha}$ and, $67 \mathrm{l} / \mathrm{ha}$ in minimal and zero tillage respectively. In conventional method of wheat production, 126 $1 /$ ha fossil fuels were needed.

Due to economizing 59.41 diesel in zero tillage technology, 124277.6 sums and 35.01 diesel in minimal technology, 73724 sums profit were gained. In zero tillage, high labour efficiency and less energy usage are important.

In zero tillage of wheat production, labour productivity and labour capacity were higher 1.5 and 2.3 times respectively in comparison with conventional. For this practice (zero tillage), FANKHAUSER 2155 (Brazil) was used to soil cultivation. Its price was \$28000 and this was 67564000 sums in currency rates of 2014.

The machine bought will be covered in 3.6 years. Afterwards, it can be used for other purposes such as sowing of cotton, mung bean, wheat and etc.

Economic efficiency evaluation of using special machines is based on the indicator of "decrease in exploitation costs". The recovery period of costs comes from balance values of machines, exploitation costs in mechanization operations, amortization sums Table 5.

$$
\begin{aligned}
\mathrm{KM}_{\mathrm{M}} & =\frac{Б_{\mathrm{I}_{\mathrm{M}}}}{\Delta X_{\text {expl }}+X_{\text {amor }}} \\
K M_{M} & =\frac{74320400}{20881253,4}=3,6 \text { year }
\end{aligned}
$$

Here: $\mathrm{K}, \mathrm{M}_{\mathrm{M}}-$ recovery period, year

$\mathrm{DK}_{\mathrm{I}_{\mathrm{M}}}$ - balance value of the machines, sums

$\Delta X_{\text {expl }}$ - decreasing sums of exploitation costs for mechanization operations, sums/year

$$
X_{\text {amor }} \text { - Amortization, sums/year }
$$

\section{Conclusion}

Based on the evaluations, it can be concluded that wheat yields were around 49.2 centner/ha in irrigated lands and profitability was $34.8 \%$, while wheat yields were 37 centner/ha, profitability was $1.8 \%$ under conventional technology. From that, it is recommended that wheat production is acceptable while yields will be more than 36 centner/ha. Resources saving technologies (minimal and zero tillage) were more efficient in terms of yields and profitability. Wheat yields were 65.4 and 67.1 centner/ha and profitability were $105.5 \%$ and $132.1 \%$ under minimal and zero tillage technologies respectively. An Overall, on the calculations, it can be stated that minimal and zero tillage technologies have advantages on the evaluation of economic indicators. Using minimal and zero tillage practices give possibility to increase labour productivity, to use resource effectively, to improve soil quality, and crop diversification.

\section{References}

1. Nurbekov Al (2008) Manual on conservation agriculture practices in Uzbekistan

2. Farooq Md, Kadambot HMS (2015) Conservation agriculture: concepts, brief history and impacts on agricultural systems. Springer International Publishing.

3. Abdullaev I, Mehmood UH, Kahramon J (2007) Water saving and economic impacts of land levelling: the case study of cotton production in Tajikistan. Irrig Drainage Syst 21: 251-263.

4. Ken EG, Ernst W, Marc C, Pablo T (2009) Conservation agriculture and smallholder farming in Africa: The heretics' view. Field Crops Research 114: 23-34.

5. Mirtalipova N (2014) Potential of conservation agriculture implementation on carbon sequestration in Tashkent Province.

6. Garc TL (2003) Conservation agriculture: environment, farmers experiences, innovations, socio-economy, policy. Kluwer Academic Publishers, London.

7. Aikins S, Afuakwa J (2012) Effect of four different tillage practices on soil physical properties under cowpea. Agriculture and Biology Journal of North America 3: 17-24.

8. Eshonkulov $\mathrm{R}$ (2004) Study of soil emission gases $\mathrm{CO}_{2}$ and $\mathrm{H}_{2} \mathrm{O}$ on the traditional and minimal technologies in the agriculture.

9. Bronzes AA (2014) Social and economic aspects of application conservation agriculture technologies in Uzbekistan.

10. Statistic data for 1991-2015, State Committee on Statistics of Uzbekistan

11. Agriculture of Uzbekistan (2015) Statistical Collection. Tashkent.

12. Dragaytsev VI, Morozov BM (2010) Methods of economic evaluation of technologies and machines in agriculture.

13. Anvar Jabborov (2014) Farming in Kashkadarya province.

14. Toshboltoev MT (2012) The system of machines and technologies for the comprehensive mechanization of agricultural production for 2011-2016.

15. Ruziyev ShM, Xamroev FX, Umarov R, Qodirov Sh (2012) Implementing resource saving technologies for cereal production in farming. Scientificpractical manual.

16. The data of the Ministry of Agriculture and Water Resources of the Republic of Uzbekistan (2014) Information on prices of agricultural products, material and technical resources on the services provided.

17. Bayirov MT (2011) Standard technologic maps for agricultural production" for 2011-2015.

18. www.agriculture.uz 